\title{
Evaluation of Acute Appendicitis Findings in Children During the COVID-19 Pandemic Containment Process
}

\section{COVID-19 Pandemisi Kısıtlama Sürecinde Çocuk Akut Apandisit Bulgularının Değerlendirilmesi}

\author{
Zerrin Özçelik', @ilknur Banlı Cesur', @Orkun Tolunay², @Özgür Külahç \\ IUniversity of Health Sciences Adana City Training and Research Hospital, Pediatric Surgery, Adana \\ 2University of Health Sciences Adana City Training and Research Hospital, Department of Pediatrics, Adana \\ ${ }^{3}$ University of Health Sciences Adana City Training and Research Hospital, Patology, Adana
}

\begin{abstract}
Aim: To evaluate the effect of the COVID-19 pandemic on patients admitted to the pediatric emergency department and operated with the diagnosis of acute appendicitis in the pediatric surgery clinic.

Material and Method: Files of patients who underwent appendectomy in the pediatric surgery clinic of Health Sciences University Adana City Training and Research Hospital between 16 March-16May 2019 and 16 March-16 May 2020 were retrospectively analyzed and divided into two groups respectively.

Results: In the study, 95 patients in Group-1 (5.1\% 95/1851) and 83 patients in Group-2 (11.5\% 83/724) was operated for acute appendicitis. There was a significant difference between the two groups in terms of the number of patients who underwent appendectomy $(p=0.001)$. A statistically significant difference was not found between the two groups when age, gender, duration of admission to hospital, preoperative laboratory values and duration of hospitalizasyon were compared. Perforated appendicitis was detected in 9 (9.5\%) of the patients who underwent appendectomy in Group-1 and in 13 (15.7\%) of the patients in Group-2 and it was not statistically significant $(p=0.007)$. The mean size of appendix of the surgical pathology specimens was found to be $8.98 \pm 3.12 \mathrm{~mm}$ in Group-1 and 10.3 $\pm 3.43 \mathrm{~mm}$ in Group-2 ( $p=0.007)$.

Conclusion: Although the number of applications to pediatric emergency services decreased during the pandemic period, there was no decrease in the number of patients operated on due to appendicitis. In addition, it was found that the rate of perforated appendicitis increased. For this reason, it should be considered that the situations requiring emergency surgery do not decrease with the epidemic.
\end{abstract}

Keywords: Appendicitis, COVID-19, Child
Öz

Amaç: COVID-19 pandemisinin çocuk acil servise başvuran ve çocuk cerrahi kliniğinde akut apandisit tanısı ile ameliyat edilen hastalar üzerindeki etkisinin değerlendirilmesi.

Gereç ve Yöntem: Sağlık Bilimleri Üniversitesi Adana Şehir Eğitim ve Araştırma Hastanesi çocuk acil servisine 16Mart-16Mayıs 2019 ile 16Mart-16Mayıs 2020 tarihleri arasında başvuran ve çocuk cerrahi kliniğinde apendektomi yapılan hastaların dosyaları retrospektif olarak incelenmiştir. Hastalar iki gruba ayrılmıștır, Grup1: 16Mart-16Mayıs 2019, Grup2: 16Mart-16 Mayıs 2020 tarihleri arasında ameliyat edilen hastalar olarak belirlenmiş̧ir. Hastaların demografik verileri, hastaneye başvuru süresi, hastanede yatış süresi, patoloji raporlarında kayıtlı olan apendiks çapı, perforasyon olup olmaması ve laboratuvar bulguları değerlendirilmiştir.

Bulgular: Çalışmada Grup1'de 95 hastaya (\%5,1 95/1851) Grup2'de 83 hastaya (\%11,5 83/724) akut apandisit nedeni ile apendektomi yapıldığı saptanmıştır. Her iki grup arasında apendektomi yapılan hasta sayısı açısından anlamlı fark saptanmıştır $(p=0,001)$. İki grup arasında yaş, cinsiyet, hastaneye başvuru süresi, ameliyat öncesi laboratuar değerleri ve hastanede yatış süresi karşılaştırıldığında istatistiksel olarak anlamlı fark saptanmamıştır. Grup1'de apendektomi yapılan hastaların 9'unda $(\% 9,5)$, grup 2'deki hastaların 13'ünde $(\% 15,7)$ perfore apandisit saptanmışve istatisktiksel olarak anlamlı fark bulunmamıştır $(p=0,07)$ Patoloji raporlarında ölçülen apendiks çapı ortalama değerleri Grup1

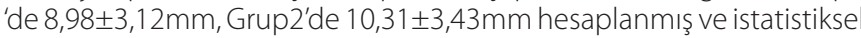
olarak anlamlı bulunmuştur ( $\mathrm{p}=0,007)$

Sonuç: Pandemi döneminde çocuk acil servislerine başvuru sayısı azalmış olmasına rağmen apandisit nedeni ile ameliyat edilen hasta sayılarında azalma görülmemiştir. Ayrıca perfore apandisit oranının artmış olduğu saptanmıştır. Bu nedenle acil cerrahi gerektiren durumların salgın ile azalmadığı konusunda uyanık olunması gerektiğ hatırlanmalıdır.

Anahtar Kelimeler: COVID-19, Çocuk, Apandisit 


\section{INTRODUCTION}

The new coronavirus disease (COVID-19) has spread rapidly all over the world since December 2019, when it was first detected in the People's Republic of China. COVID-19 has affected more than 10 million people worldwide and was declared as a pandemic by the World Health Organization (WHO) on March $11,2020 .{ }^{[1,2]}$ Due to the seriousness of the disease, strategies aimed at reducing the spread of the virus have been preferred worldwide, and each country has developed different strategies in their own conditions. Various restrictions such as interrupting face-to-face education in schools, applying restriction hours specific to age groups, and encouraging practices to stay at home voluntarily have imposed in different countries. ${ }^{[3-7]}$ The first COVID-19 cases were detected in Turkey on March 11, 2020 and similar restrictions has also begun with the increase in the number of COVID-19 cases. ${ }^{[8]}$ Although the target of the restrictions aims to manage the burden of the health system in a planned manner by reducing social movement, medical emergencies besides COVID-19 infection remained. Problems are encountered in solving emergency health problems other than COVID-19 infection due to the intensity caused by the pandemic and related conditions in the health systemand the lack of information on how individuals in the society will manage other emergency health problems during the pandemic process. Due to the difficulties brought by the pandemic, delay in the diagnosis and treatment of emergency health problems may lead to a more severe course of these diseases and increase in morbidity and mortality. ${ }^{[4,5,9-11]}$

One of the most common reason for admission to pediatric emergency service is acute abdominal pain. ${ }^{[12]}$ At a rate of 1-8\% of the children are diagnosed with acute appendicitis who applied to the emergency department with the complaint of acute abdominal pain. ${ }^{[13]}$ Early diagnosis of acute appendicitis is important in starting surgical and antibiotic treatment at the appropriate time, preventing perforation, abscess formation and other postoperative complications. ${ }^{[13-15]}$

According to the results of the study examining the applications to the pediatric emergency department, the number of emergency surgery patients applied to the pediatric emergency department has decreased in the COVID-19 pandemic restriction period between March-May 2020. ${ }^{[3,7,16]}$ In the studies, it has been determined that families are reluctant to take their children to the hospital due to the fear of catching COVID-19 and the restriction of the use of public transportation, and the difficulties in transportation to hospitals. ${ }^{[4,7,10,17,18]}$ In the present study, it was aimed to evaluate the effect of the COVID-19 pandemic on patients who were admitted to the pediatric emergency department and operated with the diagnosis of acute appendicitis on days restricted due to the COVID-19 pandemic.

\section{MATERIAL AND METHOD}

The study was designed as a retrospective cohort study. Applications to the pediatric emergency department during the restriction period due to the pandemic and the applications in the same months last year before the pandemic was examined. Files of patients who applied to the pediatric emergency department of University of Health Sciences Adana City Training and Research Hospital between 16 March-16 May 2019 and 16 March-16 May 2020 with the complaint of abdominal pain and were hospitalized in the pediatric surgery clinic and underwent appendectomy were retrospectively analyzed. Patients hospitalized for other reasons rather than abdominal pain, patients operated due to ovarian pathology, patients operated due to acute abdomen but not diagnosed with appendicitis were excluded from the study. Patients were divided into two groups. Group 1: Patients operated before pandemic (between March 16 and May 16, 2019), Group 2: Patients operated in the pandemic (between March 16 and May 16, 2020). A total of 1851 patients in Group 1 and 724 patients in Group 2 were consulted to the pediatric surgery department due to abdominal pain. The demographic data of the patients, the duration of admission to the hospital, the length of hospital stay, the diameter value of the appendix recorded in the pathology reports, the presence or absence of perforation and laboratory findings were evaluated. Ethical approval was obtained from University of Health Sciences Adana City Training and Research Hospital Clinical Research Ethics Committee (18.11.2020 / 70/133) for the study. All procedures were carried out in accordance with the ethical rules and the principles of the Declaration of Helsinki.

Statistical analysis in the study was conducted using the SPSS (Statistical Package for the Social Sciences) 23.0 package program. Categorical measurements were calculated as numbers and percentages, and continuous measurements were calculated as mean and standard deviation (median and minimum-maximum where necessary). Pearson Chi-square test statistics were used to compare categorical variables. The Shapiro-Wilk test was used to determine whether the parameters in the study show normal distribution. In the comparison of continuous measurements between the groups, by controlling the distributions, Independent Student t-test was used for binary variables with normal distribution, and Mann Whitney $u$ tests were used for more than two variables that did not show normal distribution. The statistical significance level was taken as 0.05 in all tests.

\section{RESULTS}

Demographic and clinical characteristics of the patients are shown in Table 1. Statistically significant difference was not found between the two groups when age, gender, duration of admission to hospital, preoperative laboratory values and length of hospital stay were compared (Table 1).

Comparison of postoperative diagnosis and pathological findings are shown in Table 2. In group 1, uncomplicated appendicitis was detected in $76(80 \%)$, lymphoid hyperplasia in $10(10.5 \%)$ and perforated appendicitis in $9(9.5 \%)$ of the patients who underwent appendectomy. Uncomplicated appendicitis was detected in $8(74.7 \%)$, lymphoid hyperplasia in $8(9.6 \%)$, and perforated appendicitis in $13(15.7 \%)$ of the 
patients. Although the rate of perforated appendicitis was higher in Group 2, this difference was not statistically significant $(p=0.07)$. Mean values of appendix diameter measured in pathology reports were higher in Group 2 ( $p=0.007$ ).

\begin{tabular}{|c|c|c|c|}
\hline Variables & Group 1 & Group 2 & P Value \\
\hline Number of patients & 1851 & 724 & \\
\hline Operation Status & & & 0.001 \\
\hline Unoperated patients & 1756 (94.4\%) & $641(88.5 \%)$ & \\
\hline Operated patients & $95(5.1 \%)$ & $83(11.5 \%)$ & \\
\hline Age, mean (Year \pm sd) & $11.31 \pm 4.3$ & $12.1 \pm 3.9$ & 0.19 \\
\hline Gender* & & & 0.877 \\
\hline Female, n(\%) & $61(64.2 \%)$ & $52(62.7 \%)$ & \\
\hline Male, $\mathrm{n}(\%)$ & $34(35.8 \%)$ & $31(37.3 \%)$ & \\
\hline \multicolumn{3}{|c|}{ Application period to the hospital* (days) } & 0.139 \\
\hline mean $\pm s d$ & $1.8 \pm 1.3$ & $2.2 \pm 1.5$ & \\
\hline median (min-max) & $2(1-10)$ & $2(1-10)$ & \\
\hline \multicolumn{2}{|l|}{ Length of stay at the hospital (days)* } & & 0.707 \\
\hline$(\operatorname{mean} \pm \mathrm{sd})$ & $3.3 \pm 2.3$ & $3.5 \pm 2.4$ & \\
\hline median (min-max) & $3(1-11)$ & $2(1-15)$ & \\
\hline WBC $10^{3} / \mu \mathrm{l}(\text { mean } \pm \mathrm{sd})^{*}$ & $13.9 \pm 5.6$ & $15.3 \pm 4.9$ & 0.073 \\
\hline Neutrophils \% (mean \pm sd)* & $74.4 \pm 14.2$ & $75.3 \pm 14.4$ & 0.700 \\
\hline Lymphocytes \% (mean \pm sd)* & $16.4 \pm 10.8$ & $15.4 \pm 10.6$ & 0.536 \\
\hline Thrombocytes $10^{3} / \mu \mathrm{l}$ (mean $\pm \mathrm{sd}$ )* & $311.2 \pm 93.7$ & $303.3 \pm 81.8$ & 0.553 \\
\hline C-reactive protein $\mathrm{mg} / \mathrm{L}(\operatorname{mean} \pm \mathrm{sd})^{*}$ & $37.7 \pm 53.8$ & $39.9 \pm 68.8$ & 0.829 \\
\hline Radiological evaluation* & & & 0.575 \\
\hline PA erect abdominal, $n(\%)$ & $59(62.1)$ & $53(63.9)$ & \\
\hline Ultrasound, n (\%) & $29(30.5)$ & $24(28.9)$ & \\
\hline Tomography, n (\%) & $6(6.3)$ & $3(3.6)$ & \\
\hline Ultrasound + Tomography, n (\%) & $1(1.1)$ & $3(3.6)$ & \\
\hline
\end{tabular}

Table 2. Comparison of post-operative diagnosis and pathological findings

\begin{tabular}{lccc} 
& $\begin{array}{c}\text { Group 1 } \\
\mathbf{n}(\%)\end{array}$ & $\begin{array}{c}\text { Group2 } \\
\mathbf{n}(\%)\end{array}$ & $\begin{array}{c}\text { P } \\
\text { Value }\end{array}$ \\
\hline Uncomplicated appendicitis & $76(80)$ & $62(74.7)$ & \\
Lymphoid Hyperplasia & $10(10.5)$ & $8(9.6)$ & 0.07 \\
Perforated appendicitis & $9(9.5)$ & $13(15.7)$ & \\
Total & $95(100)$ & $83(100)$ & \\
$\begin{array}{l}\text { The mean size of appendix of the surgical } \\
\text { pathology specimens (mm) (mean } \pm \text { sd) }\end{array}$ & $8.9 \pm 3.1$ & $10.3 \pm 3.4$ & 0.007 \\
\hline
\end{tabular}

\section{DISCUSSION}

The COVID-19 pandemic has caused some changes in the service provision of hospitals in our country as well as the rest of the world. During the pandemic period, there were even times when elective surgeries were stopped and only emergency operations were allowed in operating rooms. In this process, most of the inpatient services in hospitals in many centers were transformed into COVID-19 services, the number of patients admitted to polyclinics was reduced and only patients with appointments were allowed to the polyclinics. While operating room personnel and doctors were assigned to work in COVID-19 intensive care, service and emergency polyclinics, emergency services were rearranged in accordance with the pandemic.

According to the results of this study, a significant difference was found between the number of patients in group 1 and group 2. This finding indicates that the number of patients admitted to pediatric emergency clinics has decreased in the COVID-19 pandemic. ${ }^{[3,7,19,20]}$ The reasons for the decrease in pediatric emergency clinic admission are, the thought that health problems are solved with local health services, suggestions to stay at home, people do not want to enter crowded environments such as emergency services and risk of infection..$^{[4,7,18]}$ In our study, although the number of patients admitted to the pediatric emergency department during the pandemic period decreased, the number of patients operated for acute appendicitis in the pediatric surgery clinic did not decrease when compared to the last year, and even an increase was observed in the operation rates. In the study of Kvasnovsky et al., when the pandemic period was compared with the patients who underwent appendectomy in the last year, results were similar. ${ }^{[2]]}$ There are also different studies reporting that there is no decrease in pediatric appendectomies during the pandemic period. $[4,18,22]$

According to the literature, appendicitis in children is more common at the ages of 10-19 and there is a peak at 11-12 years of age. Appendicitis is more common in girls. ${ }^{[12,15,23]}$ In this study, although there was no significant difference between the groups, the age and gender distribution of the patients in the groups were compatible with the age and gender of appendicitis in the literature. In studies conducted in the pandemic, appendicitis was more common in males. $[4,17,18]$ However, in our study, females were more common in both groups. There was no significant difference between the groups in terms of admission time. There are studies reporting higher complication rate in patients with acute appendicitis with delayed admission to hospital. It has been reported that the incidence of complicated appendicitis increases especially in patients whose symptoms last than 24 hour and who undergo appendectomy. ${ }^{[4,11,17,18,24]}$ In our study, the admission time to hospital was more than 24 hours in both groups and Group 2's admission time was longer. Although there was no statistically significant difference between the two groups in terms of perforation, the higher rate of perforation during the pandemic period suggests complications due to delayed admissions. ${ }^{[11,18]}$ Our results was similar with the studies in the literature.

Studies have reported that patients who underwent appendectomy during the pandemic period had a longer length of hospital stay. ${ }^{[13,21]}$ In these studies, they reported reasons such as the patients presenting later than 24 hours, higher perforation rates, and the preoperative follow-up of patients with COVID-19 with antibiotic treatment. ${ }^{[4,7,10,11,21]}$ 
In our study, the similarity of patient hospitalization period between the groups may be related to the fact that physicians kept their hospitalization periods short to reduce the risk of COVID-19 infection during the pandemic period.

Since it is difficult to diagnose acute appendicitis in pediatric patients, clinical evaluation, laboratory evaluation and radiological examinations are used. In this study, since most of the patients were brought to the hospital under emergency conditions at night, the patients were evaluated according to physical examination and laboratory values (white blood cell, neutrophil, lymphocyte, platelet count and C-reactive protein). Adequate radiological examination could not be performed due to the difficulty of performing ultrasonography at night. However, abdominal tomography was performed deemed necessary according to the surgeon's preference. Ultrasound and abdominal tomography could be performed on very few patients in both groups. The decision for surgery was made according to physical examination and laboratory findings

In the literature, there are studies in which the diameter of the appendix is measured with radiological imaging methods. ${ }^{[25-29]}$ Romero et al. conducted a study calculating the tomographic measurement of the appendix diameter in adult patients with acute appendicitis during the pandemic period. They reported that appendix diameter was found to be higher in patients diagnosed with acute appendicitis during the pandemic period and it was statistically significant. ${ }^{[26]}$ In our study, we evaluated the appendix diameter according to the pathological measurements after the surgery, since tomography was not peformed in all of the patients and the appendix diameter was not measured in the tomography. Since there isn't study based on phatological measurements, we can't make a comparison, but the appendix diameter was found to be higher in pathological measurements in patients who underwent appendectomy during the pandemic period. It was found statistically significant.

\section{CONCLUSION}

In this study, which was carried out with the aim of evaluating the findings of appendicitis in children during the period of restriction by the COVID-19 Pandemic, it was found that the number of surgical emergencies did not decrease despite the decrease in the number of patients applied to the pediatric emergency department. It was found that the rate of operated patients increased during the pandemic period, the mean values of the measured appendix diameter were higher, and the incidence of perforated appendicitis increased.

Despite the decrease in the number of referrals to pediatric emergency services during the pandemic period, the number of patients operated on is similar and the rate of perforated appendicitis among them has increased, reminding pediatric emergency physicians and surgeons that the situations requiring emergency surgery do not decrease with the pandemic.

\section{ETHICAL DECLARATIONS}

Ethics Committee Approval: The study approved by the Ethical Committee of Adana City Training and Research Hospital, with the ethical number of 1133.

Informed Consent: Informed consent was obtained from the parents of all patients preoperatively.

Referee Evaluation Process: Externally peer-reviewed.

Conflict of Interest Statement: The authors have no conflicts of interest to declare.

Financial Disclosure: The authors declared that this study has received no financial support.

Author Contributions: All of the authors declare that they have all participated in the design, execution, and analysis of the paper, and that they have approved the final version.

\section{REFERENCES}

1. Data as received by WHO from national authorities by 10:00 CEST, Coranavirus disease 2019 (COVID-19) Situation report -158 [June 26th, 2020];Available from:https://www.who.int/docs/default-source/ coronaviruse/situation-reports/20200626-covid-19-sitrep-158. pdf?sfvrsn=1d1aae8a_2

2. Sohrabi C, Alsafi Z, O'Neill N, et al. World health organization declares global emergency:a review of the 2019 novel coronavirus (COVID-19). Int J Surg. 2020;76:71-6.

3. Dong Y, Mo X, Hu Y, et al. Epidemiology of COVID-19 Among Children in China. PEDIATRICS 2020;145;(6):1-10.

4. Orthopoulos G, Santone E, Izzo F, et. al. Increasing incidence of complicated appendicitis during COVID-19 pandemic. Am J Surg 2021;221;(5):1056-60.

5. Valderrama OC, Morales X, Ferrigni CJ, et al. Acute Care Surgery during the COVID-19 pandemic in Spain: Changes in volume, causes and complications. A multicentre retrospective cohort study. Int J Surg 2020;80:157-61.

6. Wei Y, Yu C, Zhao TX, et al. The impact of Covid-19 pandemic on pediatric operations:a retrospective study of Chinese children. Italian Journal of Pediatrics 2020;46(155):1-5.

7. Dopfer C, Wetzke M, Scharff AZ, et al. COVID-19 related reduction in pediatric emergency healthcare utilization-a concerning trend. BMC Pediatrics 2020;20:(427):1-10.

8. Demirbilek Y, Pehlivantürk G, Özgüler ZÖ, Alp Meşe E. COVID-19 outbreak control, example of ministry of health of Turkey. Turk J Med Sci. 2020;50(1):489-94.

9. Zhou Y, Cen LS. Managing acute appendicitis during the COVID-19 pandemic in Jiaxing, China. World J Clin Cases 2020;8(19):4349-59.

10. Place R, Lee J, Howell J. Rate of pediatric appendiceal perforation at a children's hospital during the Covid-19 pandemic compared with the previous year. JAMA Network Open 2020;3(12):1-3:e2027948

11. Sinapiri O, Danziger CR, Krause I, et al. Delayed diagnosis of pediatric appendicitis during the COVID-19 pandemic. Acta Paediatrica 2020;109;(8):1672-6.

12. Kaharbanda $A B$, Stevenson MD, Macias $C G$, et al. Interrater reliability of clinical findings in children with possible appendicitis. Pediatrics 2012;129;(4):695-700.

13. Rentea RM, St. Peter SD, Snyder CL. Pediatric appendicitis:state of the art review. Pediatr Surg Int 2017;33;(3):269-83.

14. Sucu A, Tolunay O, Cesur IB, et al. Relationship Between Acute Appendicitis and Platelet Indices in Childhood. J Pediatr Emerg Intensive Care Med 2018;5:98-102. 
15. Kaharbanda AB, Benitez GV, Ballard DW, et al. Development and Validation of a Novel Pediatric Appendicitis Risk Calculator (pARC). PEDIATRICS 2018;141(4):1-9.

16. Ludvigsson JF. Systematic review of COVID-19 in children shows milder cases and a better prognosis than adults. Acta Paediatrica. 2020;109;(6):1088-95.

17. Velayos M, Munoz-Serrano AJ, Estefanía-Fernández KJ, et al. Influence of the coronavirus 2 (SARS-Cov-2) pandemic on acute appendicitis. Anales Pediatria (Barc) 2020;93;(2):118-22.

18. Gerall CD, DeFazio JR, Kahan AM, et al. Delayed presentation and suboptimal outcomes of pediatric patients with acute appendicitis during the COVID-19 pandemic. J Pediatr Surg 2021;56;(5)905-10.

19. Zvizdic Z, Vranic S. Decreased number of acute appendicitis cases in pediatric population during the COVID-19 pandemi:Any link? Journal of Pediatric Surgery 2021;56;(1):199-200.

20. Isba R, Edge R, Broughton E, Francis N, Butler J. Where have all the children gone? Decreases in paediatric emergency department attendances at the start of the COVID-19 pandemic of 2020. Arch Dis Child 2020;105(7):704.

21. Kvasnovsky CL, Shi Y, Rich BS, et al. Limiting hospital resources for acute appendicitis in children:Lessons learnd from the U.S epicenter of the COVID-19 pandemic. J Pediatr Surg 2021;56(5):900-4.

22. Archer LP, Blackll S, Campbell H, Boyd D, McBride C. Increased incidence of complicated appendicitis during the COVID-19 pandemic. J Pediatr Child Health 2020;56(8):1313-4.

23. Körner H, Söndenaa K, Söreide JA, et al. Incidence of acute nonperforated and perforated appendicitis:age-specific and sex-specific analysis. World J Surg 1997;21(3):313-7

24. Pham XB, Sullins V, Kim D, et al. Factors predictive of complicated appendicitis in children. J Surg Res. 2016;206(1):62-6.

25. Katipoglu B, Aygun A, Cinar H. The effect of appendix diameter on perforation in acute appendicitis cases. Cumhuriyet Med J2019;41 (2):3927.

26. Romero J, Valencia S, Guerrero A. Acute appendicitis during coronavirus disease 2019 (COVID-19): changes in clinical presentation and CT findings. J Am Coll Radiol 2020;17(8):1011-3.

27. Gezer HÖ, Temiz A, Ezer S, İnce E Demir S, Hasbay B. Acute Appendicitis in Children;Assessment of Diagnostic Reliability of Ultrasonography. Turkish J Pediatr Dis 2021;15:123-8.

28. Pedram A, Asadian F, Roshan N. Diagnostic Accuracy of Abdominal Ultrasonography in pediatric Acute Appendicitis. Bull Emerg Trauma 2019;7(3):278-83.

29. Nielsen JW, Boomer L, Kurtovic K, et al. Reducing computed tomography scans for appendicitis by introduction of a standardized and validated ultrasonography report template. J Pediatric Surg 2015;50(1):144-8. 